http://dx.doi.org/10.30681/23588403v14i0117

\title{
POLIFONIA Y ARGUMENTACION ${ }^{1}$
}

DUCROT, O. Polifonia y argumentacion: conferencia del seminário Teoria de la Argumentación y Análisis del Discurso. Cali: Universidad del Valle, 1988.

Elisandra Benedita SZUBRIS (UNEMAT) ${ }^{2}$

Data de recebimento: $24 / 06 / 2021$

Data de aceite: $30 / 07 / 2021$

Polifonia y Argumentacion (1988) de Oswald Ducrot, linguista francês, apresenta em quatro capítulos discussões minuciosas sobre aspectos voltados aos estudos da enunciação e traz, sobretudo, contribuições para o desenvolvimento da semântica argumentativa.

O autor inicia o texto apresentando a noção de polifonia, inicialmente empregada por Michel Bakhtin, adaptada por ele na teoria polifônica da enunciação. Essa teoria questiona a ideia de unicidade do sujeito falante, mostrando que um mesmo enunciado pode apresentar vários sujeitos com estatutos linguísticos diferentes, ou seja, o sentido de um enunciado pode ser, nada mais, que o resultado das diferentes vozes que ali emergem.

O sujeito falante, nessa perspectiva, remete a diferentes funções, como a do sujeito empírico SE (autor efetivo, o produtor do enunciado); a do locutor (responsável pela enunciação, que se marca na língua através da primeira pessoa, eu, mim, me, etc.; e a do enunciador (origem dos diferentes pontos de vista que se apresentam no enunciado, não são pessoas, são "pontos de perspectivas” abstratos).

Para analisar estas funções, distingue-se os tipos de enunciados de humor e de negação, o autor explica que, necessariamente, humor e negação podem não pertencer à língua, mas uma boa descrição de língua deve mostrar as possibilidades de sua utilização. Outro aspecto analisado pelo autor trata-se da utilização dos pronomes anafóricos, em que o discurso remete a segmentos anteriores.

${ }^{1}$ Obra publicada em língua espanhola.

${ }^{2}$ Mestra em Linguística e Doutoranda pelo PPGL-UNEMAT. elisandraszubris@ hotmail.com 
Finalizando a primeira parte, o autor admite a existência de duas maneiras de se comunicar, uma séria e a outra não-séria. A primeira ocorre quando o locutor assimila um enunciador, o elegendo como o seu porta-voz; a segunda é a simples apresentação dos enunciadores. Ele conclui que a comunicação séria é a mais útil para um certo número de atividades humanas, pois aponta a distinção locutor/enunciador.

No segundo capítulo, Ducrot apresenta a noção de delocutividade, constatando, ao final, que o valor linguístico fundamental das palavras é essencialmente argumentativo, também reforça que o termo já era empregado em séculos anteriores nas gramáticas árabes. No entanto, afirma que a tradição gramatical Ocidental, embora tenha se utilizado de muitos conceitos dessas gramáticas, deixou de lado tudo o que se referia à enunciação. Apenas em 1950, e graças a Émile Benveniste, é que o termo derivação delocutiva entraria em cena sendo utilizado, posteriormente, por alguns linguistas franceses como Ascombre, Benoit e outros.

O autor explica que a delocutividade se propõe a combater a impressão de que as palavras expressam a propriedade das coisas, na verdade, a palavra tem em si um valor fundamentalmente argumentativo, a sua propriedade é criada a partir do discurso argumentativo que está no sentido primeiro da palavra. Esta noção nos mostra de que maneira integramos ou incorporamos às coisas os discursos argumentativos que fazemos sobre elas.

Tal afirmação pode ser constatada no enunciado Juan es inteligente, em que a palavra inteligente, dentre tantas coisas, pode significar um elogio, levando o destinatário a ter admiração e criar um certo tipo de comportamento em relação a João. Dessa forma, Ducrot afirma que o valor argumentativo de uma palavra é o papel que ela pode desempenhar no discurso.

No terceiro capítulo, conforme palavras de Ducrot, encontraremos a parte essencial da obra, a quem se consagra a Teoria da argumentação na língua, desenvolvida em colaboração com Jean-Claude Ascombre. Essa teoria se apresenta a partir de duas formas: a primeira chamada de forma standard trabalhada no livro L'árgumentation dans la langue(1983); e a segunda chamada de forma recente, que trabalha as noções de polifonia e topos. Este capítulo se destaca por trazer debates realizados em seis conferências na cidade de Cali em 1988. 
Nas duas primeiras conferências, Ducrot faz uma apresentação dos objetivos gerais da teoria da argumentação e discute sobre as diferenças entre enunciado e frase, e sentido e significação. Para Ducrot o sentido do enunciado pode ser explicado pela teoria polifônica, pois um enunciado pode apresentar um certo número de pontos de vista, que são os enunciadores. Diz, ainda, que são dois os elementos consistentes do enunciado: o primeiro é a apresentação dos pontos de vista dos diferentes enunciadores e o segundo é a indicação da posição do locutor em relação aos enunciadores.

Desses dois elementos podem, ainda, se distinguir três possibilidades: a do locutor de identificar-se com um dos seus enunciadores; a da aprovação do enunciador pelo locutor e da possibilidade do locutor se opor ao enunciador, rejeitando o seu ponto de vista. Todo esse movimento pode ser analisado a partir da observação da frase, pois é ela que indica as possíveis relações que constituem o sentido do enunciado, ou seja, o enunciado é a realização da frase que, por sua vez, é a entidade teórica construída pelo linguista para explicar o enunciado. Enfatiza, ainda, que a argumentação está marcada na língua ou na forma linguística, por isso, a importância de mostrar, anteriormente, a distinção entre enunciado e frase.

O debate em torno de que argumentação está marcada na língua, ainda se ressente e avança para a terceira conferência. Ducrot retoma a discussão realizada sobre a forma standard e mostra as dificuldades que ela apresenta, como a constatação de que a definição de potencial argumentativo é insuficiente para descrever o valor semântico das expressões, o que o leva a introduzir uma nova noção, a de topos.

Conforme Ducrot, a forma standard poderia salvar-se graças ao contexto da pessoa que fala, da situação externa ou interna e através de determinada ideologia a partir da qual se fala. Vejamos que o ato de dar uma ordem, por exemplo, se colocaria como um problema para a teoria da argumentação, visto que, não é oportuno dizer que uma ordem só se produz em uma situação de hierarquia.

Partindo para a quarta conferência, Ducrot mostra como as expressões argumentativas podem ser definidas pelo papel que desempenham na construção de ideologias a partir da própria enunciação. Trabalha o princípio argumentativo de topos, e diz que ele assegura a passagem do argumento para a conclusão. 
Nesse sentido, a proposta está em trabalhar a argumentação na relação com os enunciadores, procurando mostrar o caráter argumentativo dos diferentes pontos de vista que se apresentam no enunciado.

Na quinta conferência, Ducrot se dedica em explicar o caráter gradual do topos a partir das formas tópicas que orientam o discurso. O topos estabelece uma relação gradual entre duas escalas $P$ e $Q$, resultando em duas formas equivalentes, a estas duas formas o autor vai chamar de formas tópicas recíprocas. Com estas duas escalas podem-se construir ainda dois topoi contrários, cada um tendo as suas formas equivalentes entre si, ou seja, duas formas tópicas para um mesmo topos. A noção de formas tópicas recíprocas sustenta a noção do caráter argumentativo das palavras, mesmo apresentando alguns contratempos.

$\mathrm{Na}$ sexta conferência, o autor apresenta algumas conclusões gerais sobre o encadeamento argumentativo; a língua sendo considerada como um conjunto de frases que determina parcial ou totalmente as possibilidades argumentativas realizadas no discurso; a determinação pela língua que se faz, principalmente, por meio de expressões chamadas de expressões argumentativas; o valor argumentativo dos pontos de vista dos enunciadores que consiste em convocar a gradualidade dos topoi, a propósito das coisas de que se fala; as formas equivalentes do topos, chamadas de recíprocas; os operadores argumentativos que determinam a natureza das formas tópicas utilizadas; e, ainda, a relação entre a argumentação, a língua e a cultura.

O autor encerra a sexta conferência fazendo uma reflexão sobre língua e ideologia, ele diz que a língua é feita para uma sociedade que contém uma ideologia, e que se adapta a essa ideologia, a língua, por sua vez, funciona graças à ela, pois necessita dela.

No último capítulo intitulado Lingüistica y verdad, Ducrot traça um panorama de suas investigações na semântica linguística, mostrando como elas rompem com certas concepções já estabelecidas nos estudos da linguagem, sobretudo, com as concepções veritativa $e$ logicista da língua. Para tanto, apresenta construções teóricas que invalidam essas concepções, como as noções de polifonia, argumentação, delocutividade, topos etc. 
Ducrot afirma que a maioria de suas investigações foram motivadas por uma profunda insatisfação, no que diz respeito aos estudos da significação e pela forma como alguns teóricos trabalharam com essa questão ao longo do tempo.

O fechamento da obra é um bônus ao leitor. Ducrot responde Algunas perguntas entre muchas otras realizadas pelos participantes durante as seis conferências na cidade de Calli. Certamente, trata-se de um convite para refletirmos sobre uma infinidade de questões que se colocam, de modo geral, aos estudos linguísticos e sobre o encaminhar da teoria da argumentação. 